\title{
The historical aspects of polycentric urban development on the example of Barcelona
}

\author{
Mariya Khasieva* $^{*}$ \\ Moscow State University of Civil Engineering, Yaroslavskoe shosse, 26, Moscow, 129337, Russia
}

\begin{abstract}
The article concerns the problems of implementation of the modern urban planning methods and principles in the context of historical process of urbanization. Network and polycentric urban planning actively developed in 19th century and implied the equal distribution of public facilities and communications, the unification of the urban space with the connecting axes, the integration of transport and engineering infrastructure. The purpose of the article is to consider the urban planning strategies of Barcelona's renovation of 19th centuries and to define it's correspondence to the tasks of modern urban development. The relevance of the topic is determined by it's connection with problems of modern growth-oriented urban structures. The article is based on complex and system theoretical approach. Theoretical analysis of urban planning strategies and urban space development is implemented to reveal the most perspective and progressive tendencies of urban planning, which anticipated the modern principles of urban space formation. The results of the work include the characteristic of polycentric Urban structures on the example of Barcelona, the determination of it's key features. The review of researches, dedicated to the history of urban planning and the problems of modern urban planning allows to make the conclusions about the advantages of polycentric urban planing and it's perspectives in future development of the cities.
\end{abstract}

\section{Introduction}

Despite the fact that scientific and technical progress is accompanied by improvement of environmental friendliness and efficiency of industrial and engineering technologies, the human impact on the environment remains the main cause of global environmental problems. Considering this item, one of the most important goal of modern urban development is formation of environmentally sustainable and efficient urban space. It suppose the of ecological safety, energy and resource efficiency of transport and engineering infrastructure, functionally and environmentally balanced urban planning structure. At the same time, the problem of preserving the historical and cultural heritage of the urban environment is equally relevant. It is necessary to respect the architectural heritage, to take into account the historical context of the city in the process of urban restructuring and expansion, simultaneously anticipating the needs of the future development of the city. Studying the historical urban

\footnotetext{
* Corresponding author: m9288@inbox.ru
} 
development is useful in terms of modern urban planning strategies and methods, providing aesthetically and functionally balanced urban environment.

The polycentric urban structures began rapidly develop at the beginning of $20^{\text {th }}$ century, that was closely related with common development of urban studies and urban planning. In 1939 American land economist Hoyt represented his sector model of urban land use, modified the concentric zone model of city development and supposed the outward progression of growth. In 1945 Harris and Ulman formulated their multiple nuclei model in the article "The Nature of Cities". The multiple nuclei model appeared as a result of the analysis of American cities development of first half of $20^{\text {th }}$ century: it supposed that the city is organized around individual service industry objects. Old concentric model was a thing of the past.

The first attempts of conscious and planned development of European cities began mostly in 19th century. It was determined by interconnected technological, economic, social and political reasons. Technical progress, industrial development, rapid urbanization led to the increasing necessity of labor in factories of industrial cities. At the same time, mechanization of agriculture caused a decrease in the number of agricultural workers. Rapid labor migration caused a sharp increase in the number of urban population. This growth significantly exceeded the rate of housing construction and led to the disorderly compaction of urban building, the emergence in industrial areas of spontaneously located slum. At the same time, the purposive urban development policy and strategies were formed, it appeared in projects of big European cities reconstruction.

One of the goals of these projects was the decentralization of urban space, which supposed to lead to social gentrification, improved sanitation and ecological conditions, optimization of traffic flows and logistical benefits. The decentralization was achieved by creating a polycentric urban planning structure in some projects. The process of forming the polycentric urban structure during the expansion of old medieval city is explored on the material of the history of Barcelona's renovation in the article.

The purpose of the article is to consider the urban planning strategies used in Barcelona's renovation of the second half of 19th-20th centuries and to define it's correspondence to the tasks of modern urban development. This purpose includes several main tasks :

- to estimate the urban planning solution in terms of transport and engineering infrastructure;

- to assess the building density and residential areas urban planning structure from the point of further urban development possibilities;

- to evaluate the level of correspondence of urban renovation plan to peculiarities of natural landscape and environmental conditions of the region.

The relevance of the topic is determined by it's connection with modern urban development, first of all, the problems of growth-oriented urban structures. According to some researchers, the polycentric urban planning contribute to reduce urban density and pendulum migration of the population within urban agglomerations, to create conducive conditions for the further development of transport infrastructure and expansion of cities. [2, 3] In certain aspects the polycentric urban structures are more perspective in terms of longterm further urban development: the polycentric urban environment corresponds to network structure of modern social and informational space. [4, 5] Also the concept of polycentric development is considered in terms of cluster approach in urban planning: polycentricity implies the separation of the numerous territorial units in the structure of the city. These 
territorial units have their own boundaries and infrastructure connections. They also have a certain autonomy and differ from each other in a number of features and functions. It requires the individual approach in determination of the directions of further development in each of them. $[6,7]$

Researches and monographs, considered in the article, concern the spheres of urban studies, urban planning, history and theory of architecture. The historical and social aspects of urban planning are represented in works of V. Glazychev, L. Mumford. They consider the polycentric urban development in common context of urbanization and industrial development. [8, 9, 10] The polycentric urban development also is explored in terms of complex problems of modern urban development, intended to form the efficient, comfortable and growth-oriented urban environment. [11, 12]

\section{Materials and methods}

All aspects of considered problems are closely connected to each other, it determine the interdisciplinary and system methodology of the research. The article is based on complex theoretical approach. Theoretical analysis of urban planning strategies and urban space development, used in European cities of the second half of 19th-20th centuries is implemented to reveal the most perspective and progressive tendencies of urban planning, which anticipated the modern principles of urban space formation.

The bibliographical review of the researches, dedicated to the history of urban planning, the problems of modern urban planning allows to make the conclusions about further development of the cities. The problems, considered in the work implies the comprehensive and complex methodology, which combines the problem areas of urban studies, history of architecture, social aspects of urban planning. The system and complex approach, represented in this work, appeals to the technical science, as well as to the history and sociology of urban planning.

\section{Results and discussion}

In 19th century authorities of European cities took control of all aspects of urban development. In earlier epochs the main reasons of reconstruction, renovation of the planning scheme and architectural appearance were reduced to the reinforcement and the legitimation of authorities, formation the image of strong power. Inigo Jones, one of the most famous British architects of 17th century, actively involved the elements of Vitruvian architectural canon and Palladio's architectural techniques for creation his own specific architectural style, corresponding historical, political and cultural background of the British society. So, Banquet house, designed by J. Jones in 1619-1622 as the part of the Whitehall palace complex, is characterized by the mixing of baroque and classical constructive and decorative elements, which can be interpreted as a visual symbolization of the unification of the British Catholic heritage and spiritual values of Protestantism. The ideas and images of ancient culture in his work express the religious and political unity of Britain. Also Jones's architectural style was dedicated to legitimization, apotheosis the authority of the power of King James I, the founder of a new dynasty and the first ruler of a unified, imperial Britain. In paradigm of absolute monarchy the court architect was a key figure in the city planning and design of urban space. However the urban development always was strongly influenced by political process and purposes, due to urbanization it became an issue of economic interests. [11] While than the urban planning strategies were defined by the monarch decisions, in 19th century the of urban planning was realized as the result of social and economical processes. The railroads development brings to flourishing suburban infrastructure. So as the renovation 
of the urban space promoted the capitalization of city's territory, it became primarily a business.

The architectural and urban planning transformations of Paris, continued from 1853 to the end of the century. Prefect J.E. Haussmann initiated the renovation of Paris, named the "Haussmannization". It mostly formed the modern look of the French capital. Communication system interconnected into a single geometric picture of open urban spaces, squares, places of cross-sections of streets was the main feature of the new city. It pursued several goals at once. First of all, it was important in terms of providing normal conditions for urban traffic. Gentrification of the central part of the city was equally important, as well as economic development by attracting investments and creation the additional workplaces.

Another example of a fundamental city renovation, which had a similar meaning and purpose was presented in Barcelona in 1859. At the middle of 19th century Barselona, the political and historical center of Catalonia, was enclosed in the old Medieval walls. The city hadn't be rebuilt since Middle Ages and completely retained its appearance: narrow and unclean streets chaotically and randomly dispersed to the sides, spontaneous building was unaesthetic, the streets congestion caused traffic jams and unsanitary living conditions.

By 1860, with permission Spanish authorities the medieval walls of the old city were destroyed. There was a need of city renovation according to a unified urban development project. In 1859 the City Council held the municipal competition and the project of Catalan architect and urban planner Antoni Rovira i Trias was chosen among all projects. His plan supposed a radial structure of the city, an egalitarian principle of the distribution of urban infrastructure. However Spanish government in Madrid supported the project of civil engineer and urban planner Ildefons Cerdà.

The Ildefons Cerdà's project, named "L'Eixample" (Fig. 1) implied the specific orthogonal grid, consisted of the same type 20-meters wide streets. The monotonous quarters were crossed by two 50 -meters wide avenue, which united the city and suburbs: Gran Via Diagonal and Gran Via de les Corts Catalanes. Cerdà was an engineer, not an architect, he was in a manner free from the prejudices and stereotypes of the academic architectural community. At the same time, he was involved in the circle of politicians and social philosophies with socialist views, he shared new theories of hygienists. So, Cerdà intended to embody the most progressive and innovative urban planning ideas in the project of Barcelona's renovation. In his work "The Common Theory of Urbanization" he wrote that "Urbanization is based on network development". [13] The main concept of new project the was the equal distribution of public facilities and communications: each 25 quarters formed a district with it's own school and engineering infrastructure. Every 4 districts formed a canton with its own market, every 4 subdistricts formed a district with a park and a hospital. it is noteworthy that the workers' quarters were located not on the outskirts of the city, but in the center, on the territory of the Old city. 


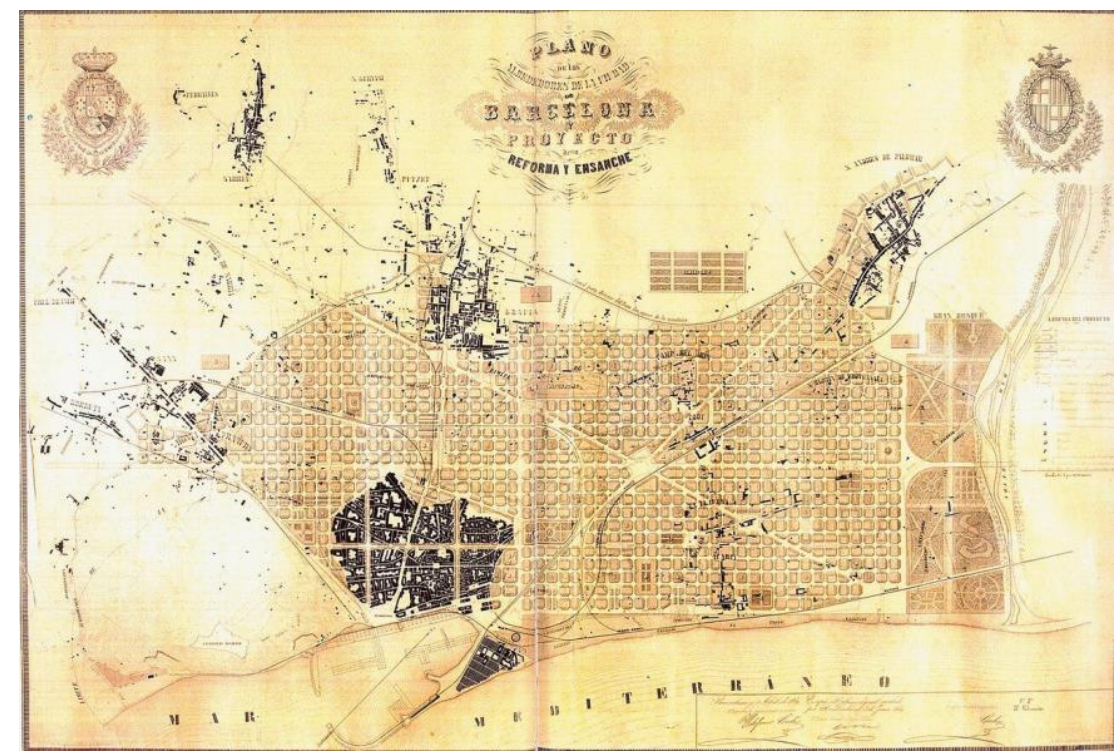

Fig. 1. Ildefons Cerdà's "L'Eixample"

The unoccupied plain lay beyond the walls of the Old medieval city, it was ideal for the expansion of the city. As a coastal city, Barcelona was strongly oriented along the coastline, this direction stayed in the planning solution. Another important peculiarity of the project, which makes it related to the plan of Haussmann's Paris is the principle of unity of urban space. Both Cerdà and Haussmann sed the planimetric and topographic surveys of the entire city to create centralized irculatory and respiratory systems of the cities.

General principles of Cerdà's work can be considered as relevant in terms of modern urban planning, because Cerdà anticipated the network urbanism and system integration, the key-issues of progress and sustainability of modern urban planning. Cerdà's city plan turned out to be perfectly adapted to new types of transport, such as the automobile, streetcars, bicycles and the metro. The orthogonal grid allows to build new city infrastructure. Cerdà's plan evolved in the context of the technological revolutions in transport. So, he added three railway lines in the third version of the plan (1863). These lines were situated from north to south, parallel to the coastline and the lines are occupied by a metro line, regional rail line, and a high-speed rail now. Although Cerdà's plan was not realized completely, the main structure and appearance of modern Barcelona formed at that time.

In 1934 the Generalitat de Catalunya made the decision to renovate particular districts of Barcelona. It could solve the tasks of expanding the city and gentrification of El Raval district, located in the Old city. To cope this problems the authorities invited Le Corbusier, who promoted the principle of straight lines in urban development: "The direct line makes the city healthier. The curve brings him ruin, all kinds of dangers and complications, paralyzes his life". [14] Le Corbusier's plan of renovated Barcelona was resembling his plan of Radiant City (Fig. 2), represented on the third meeting of the Congrès International d'Architecture Moderne in Brussels, in 1930. [15] Le Corbusier's plan of Barcelona' renovation was not realized. Further development of the city in $20^{\text {th }}$ century was predetermined by Cerdà's plan: modern transport infrastructure was easily realized in the orthogonal network layout of the city, and further compaction of buildings was implemented in the territory of indoor parks in every quarter. Cerdà attached great importance to the 
greening of city streets: parks were planned not only in every block, but in all courtyards. The desire to create a harmonious symbiosis of the natural and artificial environment makes his work related to the modern urban planning, including the creating hybrid multipurpose facilities. [16]
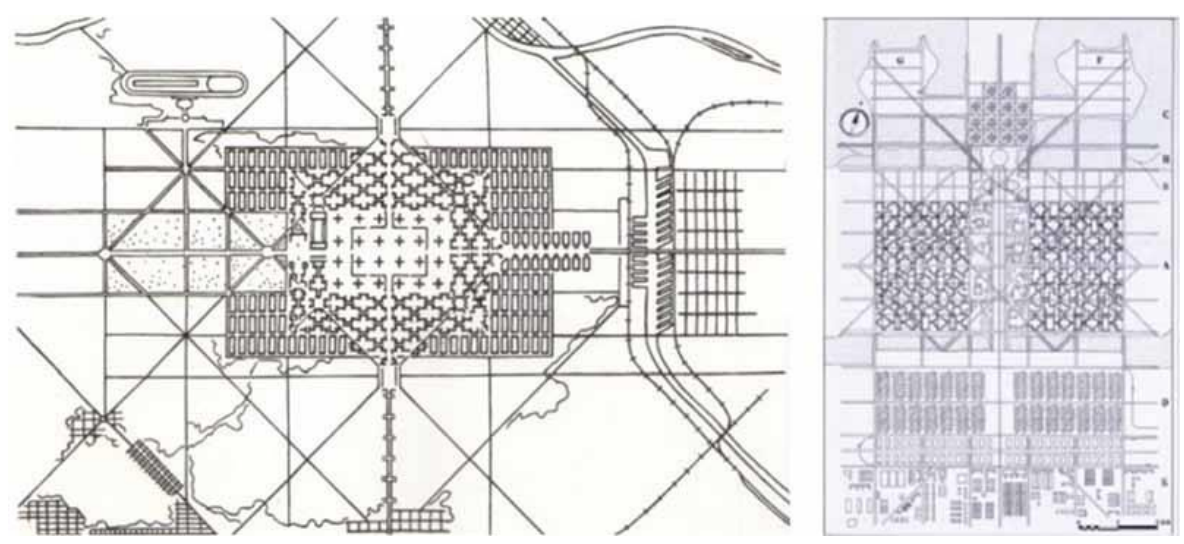

Fig. 2. Le Corbusier's "Radiant City"

Polycentric urban structure caused favorable conditions for the further growth of the Barcelona. Nowadays there are another urban planning structures, which are more efficient in terms of growth-orientation. For example, the directional grid, combines the elements of linear structure and orthogonal grid. So, one of the key parameter of modern urban planning structure is it's capacity to phased, organized and endless growth, considering regional peculiarities and infrastructure.

\section{Conclusions}

As a conclusion, the analysis of Barcelona's renovation plan revealed a few main features: - orthogonal and polycentric urban structure created favorable conditions for further transport and engineering development of the city;

- the plan of renovation also took into account the environmental and landscape conditions; - the low building density, supposed in the plan, foresaw further extension and overgrowth of the city.

The urban environment is defined as the sum of several interrelated key factors: economic, social, ecological, infrastructural. The process of urbanization forms the new problems and challenges for urban environment. The polycentric urban planning is able to cope with many challenges of urbanization: increasing of urban density and pendulum migration of the population within the city, traffic congestion. It can create conducive conditions for the further development of transport infrastructure and expansion of cities. Autonomy and self-sufficiency of each quarter are combined with equable availability of public facilities and communications, which contribute the social gentrification and harmonization.

The polycentric urban development presupposes the solution of a few main tasks: decentralization as the equal distribution of public facilities and communications, 
optimization of traffic flows and logistical benefits, gentrification and social homogenization of urban space, the improving of ecological and sanitarian conditions, great opportunities of extensive urban development. All these factors are capable to form the comfortable, efficiency and rapidly developing urban environment.

\section{References}

1. Hoyt $\mathrm{H}$. The structure and growth of residential neighborhoods in American cities. Chicago 178 (1939)

2. Harris, Chauncy D.; Ullman, Edward L. "The Nature of Cities". The Annals of the American Academy of Political and Social Science. 242, 7-17. (1945)

3. Shemyakina, V. A. Urban planning structures of the new cities of Great Britain: the end of the XIX - the beginning of the XXI century: dissertation of the candidate of architecture: 05.23.22 / Shemyakina Veronika Aleksandrovna; [Mosk. architect. in-t]. 167 (2014)

4. Mattisen W Own logic of urban landscapes of knowledge Own logic of cities: New approaches in urban studies (Moscow: New literary review) 117-192 (2017)

5. E G Krivykh IOP Conf. Ser.: Mater. Sci. Eng. 775, 012023 (2020)

6. Blagovidova N.G., Yudina N.V. Cluster method for the formation of sustainable historical settlements // Architecture and Modern Information Technologies. 4, 183-200 (2019)

7. Gaikova L.V. Polycentrism as a paradigm of development of russian cities Architecton: news of universities. 50, 69-81 (2015)

8. Glazychev, V.L. City without Borders / Moscow: Publishing House "Territory of the Future". 400 (2011)

9. Glazychev V.L. From the traditional city form to metropolis Cities of the World - World of the City (Moscow: Severnyy Palomnik Publ), available at: https://cyberleninka.ru/article/n/proektirovanie-prostranstva-v-globalnomgorodegumanitarnye-tehnologii (2009)

10. Mumford L. What is City // The City Reader/ ed. by R.T. Legates, F. Stout. — 2nd ed. — London; NY. 92-96 (2001)

11. Levy John M. Modern Urban Planning. M: Strelka Press. 390 (2020)

12. 12. Nefedov, V. Urban landscape design. Spb. 317 (2012)

13. Neuman, Michael Ildefons Cerdà and the future of spatial planning. The network urbanism of a city planning pioneer//Centenary paper TPR, 82 (2) 106-14 (2011)

14. Steyn, Gerald Le Corbusier's town-planning ideas and the ideas of history // Tshwane University of Technology. 106 (2012)

15. Le Corbusier Architecture of the 20th century, M.:"Progress" 28-29 (1977)

16. Zaykova, E. Formation methods of hybrid urban spaces in the historic city center E3S Web of Conferences 97, 01031 FORM-2019 (2019) 